\title{
Oribaculum catoniae gen. nov., sp. nov.; Catonella morbi gen. nov., sp. nov.; Hallella seregens gen. nov., sp. nov.; Johnsonella ignava gen. nov., sp. nov.; and Dialister pneumosintes gen. nov., comb. nov., nom. rev., Anaerobic Gram-Negative Bacilli from the Human Gingival Crevice
}

\author{
LILLIAN V. H. MOORE* AND W. E. C. MOORE \\ Department of Biochemistry and Anaerobic Microbiology, Virginia Polytechnic Institute \\ and State University, Blacksburg, Virginia 24061-0305
}

\begin{abstract}
The following four new species of anaerobic gram-negative bacilli isolated from the human gingival crevice are described: Oribaculum catoniae, with ATCC 51270 as the type strain; Catonella morbi, with ATCC 51271 as the type strain; Hallella seregens, with ATCC 51272 as the type strain; and Johnsonella ignava, with ATCC 51276 as the type strain. $C$. morbi is associated with periodontitis. $H$. seregens and $J$. ignava are associated with gingivitis and periodontitis. $O$. catoniae has been isolated from healthy and diseased gingiva. Dialister pneumosintes (Olitsky and Gates 1921) gen. nov., comb. nov., nom. rev., associated with gingivitis, is proposed to accommodate organisms formerly classified as Bacteroides pneumosintes.
\end{abstract}

Many undescribed species of bacteria occur among the floras of the human gingival crevice and periodontal pockets $(6,8-14)$. Among these are organisms previously referred to as "Bacteroides D19" $(9,11,12)$, "Bacteroides D26" $(9,14)$, and "Bacteroides D42" $(9,13)$, as well as one additional species ("Bacteroides D12") that we have not reported previously. We have found that "Bacteroides D19" is associated with gingivitis $(11,12)$ and periodontitis (9) and that "Bacteroides D42" is associated with periodontitis $(9,13)$, whereas "Bacteroides D26" is associated principally with oral health $(9,14)$. One purpose of this study was to describe these four species.

In addition, we propose reclassification of Bacteroides pneumosintes, a relatively common oral species that has been associated with gingivitis $(1,11,12)$ and various infections above the diaphragm (3). This species is a small, non-fermentative, gram-negative, anaerobic rod, originally isolated from nasopharyngeal secretions of patients with influenza during the epidemics of 1918 through 1921 (15). In 1970 the species was reclassified in the genus Bacteroides by Holdeman and Moore (4). This nonfermentative species was excluded from the genus Bacteroides as redefined by Shah and Collins (16), and its taxonomic position currently is incertae sedis.

\section{MATERIALS AND METHODS}

Bacterial strains. Unless otherwise stated, all strains were from our Virginia Polytechnic Institute and State University Anaerobe Laboratory Culture Collection and were isolated from the gingival crevices of clinically healthy persons or persons with gingivitis or periodontitis.

Characterization of strains. Tests to determine fermentation, enzymatic properties, fermentation products, and antimicrobial susceptibility in prereduced media and polyacrylamide gel electrophoresis of soluble proteins were performed as described previously $(2,7)$.

To determine cellular fatty acids, unless indicated otherwise, actively growing cultures were inoculated into tubes containing $10 \mathrm{ml}$ of prereduced anaerobically sterilized peptone-yeast extract-glucose (PYG) broth (2). Cultures were inoculated 7126.

\footnotetext{
${ }^{*}$ Corresponding author. Phone: (703) 231-7110. Fax: (703) 231-
}

under an oxygen-free carbon dioxide atmosphere or under an atmosphere containing an oxygen-free $10 \%$ carbon dioxide$90 \%$ nitrogen gas mixture. Tubes were stoppered with neoprene stoppers and were incubated at $37^{\circ} \mathrm{C}$. All subsequent steps in sample preparation, including centrifugation, were done in the same tubes closed with Teflon-lined screw caps under an aerobic atmosphere.

Sedimented cells from cultures that had been incubated at $37^{\circ} \mathrm{C}$ for 18 to $24 \mathrm{~h}$ were used immediately or were frozen and later thawed. Cells were lysed and saponified and the acids were extracted as described previously (5). A $2-\mu$ l portion of washed extract was chromatographed on a fused-silica capillary column with a model HP-5890A chromatograph (HewlettPackard Co., Palo Alto, Calif.) equipped with a flame ionization detector and a model HP-3392A integrator (HewlettPackard). The gas flow rates were ca. $400 \mathrm{ml} / \mathrm{min}$ for air, 30 $\mathrm{ml} / \mathrm{min}$ for hydrogen, and $30 \mathrm{ml} / \mathrm{min}$ for nitrogen. The temperatures used were $250^{\circ} \mathrm{C}$ for the injection port and $300^{\circ} \mathrm{C}$ for the detector. After injection, the oven temperature was increased from 170 to $270^{\circ} \mathrm{C}$ at a rate of $5^{\circ} \mathrm{C} / \mathrm{min}$ and then from 270 to $310^{\circ} \mathrm{C}$ at a rate of $30^{\circ} \mathrm{C} / \mathrm{min}$, held at $310^{\circ} \mathrm{C}$ for $2 \mathrm{~min}$, and then returned to $170^{\circ} \mathrm{C}$ before the next sample was injected. A standard mixture containing known fatty acids $\left(\mathrm{C}_{9}\right.$ through $\mathrm{C}_{20}$ straight-chain acids and $\left(\mathrm{C}_{10: 0} 2-\mathrm{OH}, \mathrm{C}_{13: 0} 3-\mathrm{OH}, \mathrm{C}_{14: 0} 2-\mathrm{OH}\right.$, $\mathrm{C}_{14: 0} 3-\mathrm{OH}$, and $\left.\mathrm{C}_{16: 0} 2-\mathrm{OH}\right)$ was chromatographed at the beginning of each day on which samples were analyzed and after each set of 10 samples was chromatographed.

We used the MIS software package (Microbial ID, Inc., Newark, Del.) to identify the peaks (by retention time) and to determine the area, the ratio of area to height, the equivalent chain length, the total area, and the total area of named or listed compounds. The MIS software package also was used to calculate the percentage of area for each named or listed compound compared with the total area of the compounds detected. Identification was accomplished by using the Moore Broth Library, version 3.8 (Microbial ID, Inc.).

For Johnsonella strains, which produced low turbidity in broth cultures, two to four 10-ml PYG cultures were pooled to obtain a larger cell pellet, and the extract was concentrated before analysis by evaporation under a stream of grade 50 nitrogen. For strains of Dialister pneumosintes, which normally produce no visible turbidity in broth, four to six $10-\mathrm{ml} P Y G$ 
TABLE 1. Characteristics of species in new genera of anaerobic gram-negative rods ${ }^{a}$

\begin{tabular}{|c|c|c|c|c|c|c|}
\hline \multirow[b]{2}{*}{ Characteristic } & \multicolumn{2}{|c|}{ O. catoniae } & \multicolumn{2}{|c|}{ C. morbi } & \multicolumn{2}{|c|}{ H. seregens $s^{b}$} \\
\hline & $\begin{array}{c}\text { Strain ATCC } \\
51270^{\mathrm{Tc}}\end{array}$ & $\begin{array}{l}84 \text { other } \\
\text { strains }^{d}\end{array}$ & $\begin{array}{c}\text { Strain ATCC } \\
51271^{\mathrm{TC}}\end{array}$ & $\begin{array}{l}8 \text { other } \\
\text { strains }^{d}\end{array}$ & $\begin{array}{c}\text { Strain ATCC } \\
51272^{\mathrm{T} e}\end{array}$ & $\begin{array}{l}5 \text { other } \\
\text { strains }^{d}\end{array}$ \\
\hline Amygdalin acid & - & 0 & - & 25 & - & 0 \\
\hline Arabinose acid & - & 0 & - & 12 & + & 100 \\
\hline Cellobiose acid & - & 0 & + & 62 & + & 86 \\
\hline Dextrin acid & W & 28 & + & 60 & + & 100 \\
\hline Esculin acid & - & 0 & - & 0 & - & 14 \\
\hline Esculin hydrolysis & - & 0 & + & 100 & + & 100 \\
\hline Fructose acid & - & 55 & - & 0 & + & 100 \\
\hline Glucose acid & + & 93 & + & 86 & + & 100 \\
\hline Gum arabic acid & - & 0 & - & 0 & + & 100 \\
\hline Glycogen acid & $\mathrm{W}^{e}$ & $93^{e}$ & - & $62^{e}$ & + & 100 \\
\hline Inulin acid & - & 0 & - & 0 & + & 100 \\
\hline Lactose acid & + & 87 & + & 71 & + & 100 \\
\hline Larch arabino-galactan acid & - & 0 & - & 0 & + & 100 \\
\hline Maltose acid & $t^{e}$ & $85^{e}$ & + & $71^{e}$ & + & 100 \\
\hline Mannose acid & + & 85 & - & 14 & + & 100 \\
\hline Melezitose acid & - & 0 & - & 14 & - & 0 \\
\hline Melibiose acid & - & 0 & - & 28 & + & 86 \\
\hline Pectin acid & - & 0 & - & 0 & + & 100 \\
\hline Raffinose acid & - & 27 & + & 100 & + & 100 \\
\hline Rhamnose acid & - & 0 & + & 88 & + & 86 \\
\hline Ribose acid & - & 0 & - & 0 & + & 100 \\
\hline Salicin acid & - & 0 & - & 37 & - & 28 \\
\hline Starch acid & $t^{e}$ & $80^{e}$ & $-{ }^{e}$ & $12^{e}$ & + & 100 \\
\hline Starch hydrolysis & + & $73^{e}$ & $-{ }^{e}$ & $80^{\circ}$ & + & 100 \\
\hline Sucrose acid & - & 88 & + & 100 & + & 100 \\
\hline Trehalose acid & - & $20^{e}$ & - & $25^{e}$ & W & 28 \\
\hline Xylose acid & - & 0 & - & 12 & + & 100 \\
\hline \multicolumn{7}{|l|}{ Digestion of: } \\
\hline Gelatin & + & 85 & - & 38 & - & 100 \\
\hline Milk & - & 20 & - & 0 & - & 0 \\
\hline Meat & - & 18 & - & 0 & - & 0 \\
\hline Milk curd & + & 65 & + & 100 & - & 43 \\
\hline $\mathrm{H}_{2} \mathrm{~S}$ production in $\mathrm{SIM}^{f}$ & - & 41 & - & 0 & - & 0 \\
\hline Growth in PYG-20\% bile & - & - to $\operatorname{tr}$ & - & - & - & - to $\operatorname{tr}$ \\
\hline \multicolumn{7}{|l|}{ Resistance to: } \\
\hline Erythromycin $(3 \mu \mathrm{g} / \mathrm{ml})$ & - & 2 & - & 0 & - & 0 \\
\hline Penicillin G $(2 \mathrm{U} / \mathrm{ml})$ & - & 6 & - & 0 & - & 14 \\
\hline Tetracycline $(6 \mu \mathrm{g} / \mathrm{ml})$ & - & 1 & - & 0 & - & 14 \\
\hline $\begin{array}{l}\text { Fermentation acids in PYG } \\
\text { broth }^{g}\end{array}$ & P,S,a,l,iv & $\mathrm{P}, \mathrm{a}, \mathrm{s}, \mathrm{l}, \mathrm{iv},(\mathrm{f})$ & A,f,l & $\mathrm{A}, \mathrm{f}, \mathrm{l}$ & $\mathrm{S}, \mathrm{A}, \mathrm{I}$ & $\mathrm{S}, \mathrm{a}, \mathrm{l}$ \\
\hline
\end{tabular}

${ }^{a}$ No strain ferments erythritol, mannitol, or sorbitol; indole and catalase are not produced; nitrate is not reduced; no lecithinase or lipase is detected on egg yolk agar plates (2). No strain is resistant to chloramphenicol $(12 \mu \mathrm{g} / \mathrm{ml})$ or clindamycin $(1.6 \mu \mathrm{g} / \mathrm{ml})$.

${ }^{b}$ Serum was added to all media.

$c_{+}$, acid $(\mathrm{pH}<5.5)$ or positive reaction; $\mathrm{W}$, weakly acidic $(\mathrm{pH} 5.5$ to 5.7$)$; - , negative reaction or $\mathrm{pH}>5.7$; $\mathrm{T}$, type strain.

${ }^{d}$ The values are percentages of strains positive; - , negative; $\mathrm{tr}$, trace.

${ }^{e}$ A positive or acid reaction occurs when serum $(10 \%$, vol/vol) is added to the medium, but usually the reaction is not positive in the absence of serum.

${ }^{f}$ SIM, sulfide-indole motility medium.

${ }^{g} \mathrm{~A}$ and a, acetic acid; f, formic acid; iv, isovaleric acid; 1 , lactic acid; $\mathrm{P}$, propionic acid; $\mathrm{S}$ and s, succinic acid. Uppercase letters, $>1$ meq/100 ml of culture; lowercase letters, $<1 \mathrm{meq} / 100 \mathrm{ml}$ of culture. Parentheses indicate that a product may or may not be produced.

cultures were required to obtain a sufficient cell pellet for extraction, and the resulting extract was concentrated by evaporation.

\section{RESULTS AND DISCUSSION}

Fermentative species. Reactions and properties of the three fermentative species, "Bacteroides D26," "Bacteroides D42," and "Bacteroides D12" (Oribaculum catoniae, Catonella morbi, and Hallella seregens, respectively) are shown in Tables 1 and 2.

"Bacteroides D26", a saccharolytic organism that does not grow well in the presence of $20 \%$ bile and has a DNA G+C content of $49 \mathrm{~mol} \%$, is most like species of the genus Prevotella. However, cultures of Prevotella strains grown in PYG broth produce major amounts of succinic acid and only trace to moderate amounts of propionic acid, whereas cultures of "Bacteroides D26" grown in PYG broth produce moderate to major (usually major) amounts of propionic acid and moderate to major (usually moderate) amounts of succinic acid (Table 1). The production of major amounts of propionic acid resembles a characteristic of Megamonas strains, but the $\mathrm{G}+\mathrm{C}$ content of the DNAs of Megamonas (Bacteroides hypermegas) strains is $35 \mathrm{~mol} \%$ (3), a value which is $14 \mathrm{~mol} \%$ lower than the $\mathrm{G}+\mathrm{C}$ content of "Bacteroides D26." Also, the cellular fatty acids of "Bacteroides D26" are different from those of Prevotella or Megamonas strains. Strains of "Bacteroides D26" $(O$. catoniae) contain $15 \%$ iso- $\mathrm{C}_{13: 0}, 26 \%$ iso- $\mathrm{C}_{15: 0}$, and only $23 \%$ anteiso- $\mathrm{C}_{15: 0}$ (Table 2), compared with $1 \%$ iso- $\mathrm{C}_{13: 0}, 10 \%$ 
TABLE 2. Cellular fatty acid compositions of Johnsonella, Oribaculum, Hallella, Catonella, and Dialister species, expressed as mean percentages of the total acids

\begin{tabular}{|c|c|c|c|c|c|c|c|c|c|c|c|c|c|}
\hline \multirow{2}{*}{ Species } & \multicolumn{13}{|c|}{$\%$ of total acids ${ }^{a}$} \\
\hline & $\begin{array}{l}\text { Unknown } \\
\text { ECL } 9.74^{b}\end{array}$ & $\begin{array}{c}\mathrm{i}-13: 0 \\
\mathrm{FA}\end{array}$ & $\begin{array}{c}\mathrm{i}-14: 0 \\
\mathrm{FA}\end{array}$ & $\begin{array}{l}14: 0 \\
\text { FA }\end{array}$ & $\begin{array}{c}14: 0 \\
\text { DMA }\end{array}$ & $\begin{array}{c}\mathrm{i}-15: 0 \\
\text { FA }\end{array}$ & $\begin{array}{c}a-15: 0 \\
F A\end{array}$ & $\begin{array}{c}\text { i-16:0 } \\
\text { FA }\end{array}$ & $\begin{array}{c}16: 1 \text { cis }-9 \\
\text { FA }\end{array}$ & $\begin{array}{l}16: 0 \\
\mathrm{FA}\end{array}$ & $\begin{array}{c}16: 0-3-\mathrm{OH} \\
\text { FA }\end{array}$ & $\begin{array}{c}18: 1 \text { cis }-9 \\
\text { FA }\end{array}$ & $\begin{array}{l}18: 0 \\
\text { FA }\end{array}$ \\
\hline O. catoniae & & 15 & & 7 & & 26 & 23 & & 1 & 5 & 1 & 1 & \\
\hline C. morbi & & & & 42 & 14 & & & & 2 & 12 & & 5 & 4 \\
\hline$H$. seregens & & & 15 & 11 & & & 5 & 15 & 2 & 23 & 16 & 3 & 2 \\
\hline J. ignava & 45 & & & 8 & & & & & 2 & 15 & & 5 & 4 \\
\hline D. pneumosintes & & & & 5 & & & & & 11 & 20 & & 21 & 12 \\
\hline
\end{tabular}

${ }^{a}$ The percentages for all acids that were present in any species at a level greater than $10 \%$ are shown. FA, fatty acid; DMA, dimethyl acetal.

${ }^{b}$ ECL 9.74, equivalent chain length of 9.74 .

iso- $\mathrm{C}_{15: 0}$, and 35\% anteiso- $\mathrm{C}_{15: 0}$ in Prevotella strains; none of these compounds has been detected in extracts of Megamonas strains (unpublished data). Of the anaerobic gram-negative, rod-shaped organisms that we have studied, no other genus contains more than $4 \%$ iso- $\mathrm{C}_{13: 0}$ fatty acid (unpublished data); most do not contain any. For these reasons we propose a new genus and species, Oribaculum catoniae, for the organisms that we previously designated "Bacteroides D26."

Description of Oribaculum gen. nov. Oribaculum (O.ri.ba'cu. lum. L. n. os, oris, mouth; L. neut. n. baculum, stick, rod; N. L. neut. n. Oribaculum, mouth rod, because the organism was first isolated from the human mouth). Oribaculum cells are obligately anaerobic, gram-negative, nonmotile, nonsporing rods that ferment carbohydrates and produce major to moderate (usually major) amounts of propionic acid and moderate amounts of acetic, succinic, and lactic acids. The major cellular fatty acids in cells grown in PYG broth are iso- $\mathrm{C}_{15: 0}$, anteiso$\mathrm{C}_{15: 0}$, and iso- $\mathrm{C}_{13: 0}$ (Table 2).

The type species is Oribaculum catoniae.

The $\mathrm{G}+\mathrm{C}$ content of the DNA of the type species is 49 mol\%.

The genus can be differentiated from phenotypically similar taxa by the $\mathrm{G}+\mathrm{C}$ content of its DNA, its production of large amounts of propionic acid in PYG cultures, and its distinctive pattern of cellular fatty acids.

Description of Oribaculum catoniae sp. nov. Oribaculum catoniae (ca.to'ni.ae. L. gen. n. catoniae, of Cato, in honor of Elizabeth P. Cato, a United States microbiologist). The description below is based on studies of the type strain and 84 other strains. Cells of the type strain grown in PYG broth are $0.6 \mu \mathrm{m}$ wide by 0.8 to $1.7 \mu \mathrm{m}$ long and occur in pairs and short chains. Cells grown in media containing a fermentable carbohydrate may be highly vacuolated. Surface colonies on blood agar plates incubated for 2 days are 0.5 to $2 \mathrm{~mm}$ in diameter, circular, entire, flat to low convex, and transparent. Although most strains are not hemolytic on rabbit blood agar, an occasional strain may be beta-hemolytic. No colonies with a dark pigment are produced.

Abundant growth occurs in peptone-yeast extract or PYG broth. Broth cultures are turbid with a smooth to fine granular sediment. The pH of PYG broth cultures is 5.0 to 5.5.

The following amounts of fermentation acids (in milliequivalents per $100 \mathrm{ml}$ of culture; mean \pm standard error of the mean) are produced in PYG broth cultures: propionic acid, $2.3 \pm 0.2$; acetic acid, $0.9 \pm 0.06$; succinic acid, $0.8 \pm 0.1$; lactic acid, $0.6 \pm 0.1$; and isovaleric acid, $0.2 \pm 0.02$. Trace to moderate amounts of formic acid may be produced. No hydrogen is detected in the headspace gas of PYG broth cultures.

Additional characteristics of the species are shown in Tables 1 and 2.
Isolated from the gingival crevices of humans with gingivitis or periodontitis and from persons with healthy gingiva.

Type strain: ATCC 51270 (= VPI N3B-3).

The $\mathrm{G}+\mathrm{C}$ content of the type strain is $49 \mathrm{~mol} \%$.

For distinctive characteristics, see the genus description above.

"Bacteroides D42" is an anaerobic gram-negative, saccharolytic, rod-shaped organism that has a DNA G+C content of 34 mol\%. In PYG broth, strains produce major amounts of acetic acid and moderate amounts of formic and lactic acids. The $\mathrm{G}+\mathrm{C}$ content of the DNA is within the range of values found for the genera Anaerorhabdus (34 mol\%), Fusobacterium (26 to 34 mol\% for most species), and Megamonas ( $35 \mathrm{~mol} \%$ ), but "Bacteroides D42" does not produce major amounts of propionic acid, as Megamonas strains do, major amounts of butyric acid, as Fusobacterium strains do, or major amounts of lactic acid, as Anaerorhabdus strains do. Therefore, we consider "Bacteroides D42" to be a new species in a new genus, for which we propose the name Catonella morbi.

Description of Catonella gen. nov. Catonella (Ca.to.nel'la. N. L. fem. n. Catonella, in honor of Elizabeth P. Cato, a United States microbiologist). Catonella cells are obligately anaerobic, gram-negative, nonmotile, nonsporing rods that ferment carbohydrates and produce major amounts of acetate and smaller amounts of formate and lactate. The major cellular constituents include $C_{14: 0}$ fatty acid, $C_{14: 0}$ dimethyl acetal, and $C_{16: 0}$ fatty acid, as determined by examining a concentrated extract obtained from two to three 10-ml PYG broth cultures (containing no serum) incubated for 2 to 4 days (Table 2).

The type species is Catonella morbi.

The $\mathrm{G}+\mathrm{C}$ content of the DNA of the type species is 34 mol\%.

The genus Catonella is differentiated from other genera of anaerobic, gram-negative, rod-shaped organisms by the $\mathrm{G}+\mathrm{C}$ content of its DNA, its fermentation products, and its cellular fatty acids.

Description of Catonella morbi sp. nov. Catonella morbi, (mor'bi. L. gen. n. morbi, of disease, because originally the organism was isolated from diseased periodontal pockets). The description below is based on studies of the type strain and seven other strains. Cells of the type strain from PYG broth cultures are 0.7 to $1.2 \mu \mathrm{m}$ wide by 1.6 to $4.0 \mu \mathrm{m}$ long and occur in pairs and short chains. Central swellings sometimes occur in media containing a fermentable carbohydrate. Surface colonies on blood agar plates incubated at $37^{\circ} \mathrm{C}$ for 2 days are $1 \mathrm{~mm}$ in diameter, circular, entire, convex, and opaque. Rabbit erythrocytes are not hemolyzed, and no colonies with a dark pigment are produced.

Serum $(10 \%, \mathrm{vol} / \mathrm{vol})$ enhances growth and usually is required to detect carbohydrate fermentation. There is moderate turbidity with limited sediment in peptone-yeast extract-serum 
broth cultures and moderately heavy turbidity with a smooth sediment in PYG-serum broth cultures. The final $\mathrm{pH}$ of PYG-serum broth cultures is 5.0 to 5.6 .

The following amounts of fermentation acids (in milliequivalents per $100 \mathrm{ml}$ of culture; mean \pm standard error of the mean) are produced in PYG-serum broth cultures: acetic acid, $2.2 \pm 0.2$; formic acid, $0.6 \pm 0.1$; and lactic acid, $0.4 \pm$ 0.1 . Abundant hydrogen is detected in the headspace gas of PYG-serum broth cultures.

Additional characteristics of the species are shown in Tables 1 and 2.

Isolated from the gingival crevices of humans with adult periodontitis.

Type strain: ATCC 51271 (= VPI D154F-12).

The $\mathrm{G}+\mathrm{C}$ content of the DNA of the type strain is $34 \mathrm{~mol} \%$.

For distinctive characteristics, see the description of the genus Catonella above.

"Bacteroides D12" is an anaerobic, gram-negative, rodshaped organism that produces major amounts of succinic and acetic acids and has a DNA G $+\mathrm{C}$ content of $58 \mathrm{~mol} \%$, a value which is similar to the $\mathrm{G}+\mathrm{C}$ contents of Mitsuokella multiacida (56 to $58 \mathrm{~mol} \%$ ) and Rikenella microfusus (60 to $61 \mathrm{~mol} \%$ ) (3) (Bacteroides multiacidus and Bacteroides microfusus, respectively). "Bacteroides D12" (Hallella) strains contain $\mathrm{C}_{16: 0}$ and $\mathrm{C}_{14: 0}$ fatty acids (Table 2), like the strains of several other genera of anaerobic gram-negative bacilli, but the production of $15 \%$ iso- $\mathrm{C}_{14: 0}$ fatty acid and $16 \% \mathrm{C}_{16: 0} 3-\mathrm{OH}$ fatty acid by this organism is distinctive among the anaerobic gram-negative bacilli (unpublished data). "Bacteroides D12" contains no iso- $\mathrm{C}_{15: 0}$ fatty acid, which accounts for $36 \%$ of the fatty acids in Rikenella strains (unpublished data), whereas Mitsuokella strains contain no $\mathrm{C}_{16: 0} 3-\mathrm{OH}$ fatty acid and half as much $\mathrm{C}_{16: 0}$ fatty acid as "Bacteroides D12" does (unpublished data). Furthermore, "Bacteroides D12" is much more fermentative than Rikenella microfusus.

Therefore, we believe that "Bacteroides D12" represents a distinct genus and species, for which we propose the name Hallella seregens.

Description of Hallella gen. nov. Hallella (Hall.el'la. N. L. masc. n. Hallella, in honor of Ivan C. Hall, a United States microbiologist). Hallella cells are obligately anaerobic, gramnegative, nonmotile, nonsporing rods that ferment carbohydrates and produce major amounts of succinic acid, moderate to major amounts of acetic acid, and moderate amounts of lactic acid. No hydrogen is detected. The major constituents of cells grown in PYG broth without serum include $C_{16: 0}$ fatty acid, $\mathrm{C}_{16: 0} 3-\mathrm{OH}$ fatty acid, iso- $\mathrm{C}_{16: 0}$ fatty acid, iso- $\mathrm{C}_{14: 0}$ fatty acid, and $C_{14: 0}$ fatty acid.

The type species is Hallella seregens.

The $\mathrm{G}+\mathrm{C}$ content of the DNA of the type species is 58 mol\%.

The genus can be differentiated from phenotypically similar taxa by its cellular fatty acid profile, particularly the relatively large amounts of $\mathrm{C}_{16: 0} 3-\mathrm{OH}$, iso- $\mathrm{C}_{16: 0}$, and iso- $\mathrm{C}_{14: 0}$ fatty acids produced, and by the high $\mathrm{G}+\mathrm{C}$ content of its DNA.

Description of Hallella seregens sp. nov. Hallella seregens (se're.gens. L. n. serum, serum; L. part. adj. egens, needing; N. L. adj. seregens, needing serum). The description below is based on studies of the type strain and five other strains. Cells of the type strain are 0.9 to $1.5 \mu \mathrm{m}$ wide by 1.2 to $6.2 \mu \mathrm{m}$ long, have swellings up to $2.4 \mu \mathrm{m}$ wide, and occur singly and in short chains. Colonies on anaerobic blood agar plates incubated for 2 days at $37^{\circ} \mathrm{C}$ are $2 \mathrm{~mm}$ in diameter, circular, entire, convex, translucent, and shiny. No hemolysis occurs on rabbit blood agar; no colonies with a dark pigment are produced.

Serum $(10 \%, \mathrm{vol} / \mathrm{vol})$ enhances growth in broth and some- times is required for fermentation. Moderate turbidity is produced in peptone-yeast extract-serum broth cultures, and abundant turbidity with a smooth white to cream sediment is produced in PYG-serum broth cultures. The $\mathrm{pH}$ of $\mathrm{PYG}-$ serum broth cultures incubated for 3 to 5 days is 4.7 to 5.2 .

The following amounts of fermentation acids (in milliequivalents per $100 \mathrm{ml}$ of culture; mean \pm standard error of the mean) are produced in PYG-serum broth cultures: succinic acid, $2.9 \pm 0.5$; acetic acid, $0.9 \pm 0.2$; and lactic acid, $0.2 \pm 0.1$. No hydrogen gas is detected.

Additional characteristics of the species are shown in Tables 1 and 2.

Isolated from the gingival crevices of humans with gingivitis or periodontitis.

Type strain: ATCC 51272 (= VPI D238B-15).

The $\mathrm{G}+\mathrm{C}$ content of the type strain is $58 \mathrm{~mol} \%$.

For distinctive characteristics, see the genus description above.

Nonfermentative species. The nonfermentative, nonproteolytic, nonpigmenting species previously referred to as "Bacteroides D19" has a DNA G+C content of $32 \mathrm{~mol} \%$ and produces moderate amounts of acetate and isovalerate and trace amounts of lactate, succinate, isobutyrate, and butyrate in PYG broth cultures. The cellular fatty acids of this species are shown in Table 2. These characteristics are most like those of Tissierella praeacuta, but the cellular fatty acids of Tissierella strains (unpublished data) do not include a compound that has an equivalent chain length of 9.74 , which accounts for $42 \%$ of the fatty acids found in "Bacteroides D19." Also, the relative amounts of fermentation acids produced by the two species are different. Because of its unique cellular fatty acid profile, we consider "Bacteroides D19" to be unlike previously described genera of nonmotile, anaerobic, gram-negative rods and propose for it a new genus and species, Johnsonella ignava.

Description of Johnsonella gen. nov. Johnsonella (John.son. el'la. N. L. masc. n. Johnsonella, in honor of John L. Johnson, a United States microbiologist). Johnsonella cells are obligately anaerobic, gram-negative, nonmotile, nonsporing, nonfermentative rods that produce a moderate amount of acetate and trace amounts of isovalerate, lactate, succinate, isobutyrate, and butyrate in PYG broth cultures. No dark colonies are produced on rabbit blood agar plates. The major cellular constituents include an unidentified compound with a retention time that indicates that it has an equivalent chain length of 9.740 and $\mathrm{C}_{16: 0}$ fatty acid.

The type species is Johnsonella ignava.

The $\mathrm{G}+\mathrm{C}$ content of the DNA of the type species is 32 mol\%.

This genus can be differentiated from other genera of anaerobic gram-negative bacilli by its cellular fatty acid profile (an unidentified acid with an equivalent chain length of 9.74 accounts for $42 \%$ of the fatty acids) and by its $\mathrm{G}+\mathrm{C}$ content and metabolic products.

Description of Johnsonella ignava sp. nov. Johnsonella ignava (ig.na'va. L. fem. adj. ignava, sluggish, because of the inactivity of this organism in vitro). The description below is based on studies of the type strain and 10 other strains. Cells of the type strain in PYG broth cultures are $0.8 \mu \mathrm{m}$ wide by 3.7 to $6.4 \mu \mathrm{m}$ long and occur singly and in pairs. Some cells have central swellings. Surface colonies on blood agar plates are minute to $2 \mathrm{~mm}$ in diameter, circular, entire, low convex, white to tan, shiny, smooth, and sometimes mottled. No hemolysis occurs around colonies grown on rabbit blood agar, and no colonies with a dark pigment are produced.

A small amount of granular, smooth, or stringy sediment, without turbidity, is produced in broth cultures. 
Amygdalin, arabinose, cellobiose, erythritol, esculin, fructose, glucose, glycerol, glycogen, gum arabic, inositol, lactose, larch arabinogalactan, maltose, mannitol, mannose, melezitose, melibiose, raffinose, rhamnose, ribose, salicin, sorbitol, starch, sucrose, trehalose, xylan, and xylose are not fermented. No hydrogen sulfide is produced in SIM (sulfide-indole motility) medium (BBL Microbiology Systems, Baltimore, Md.). No growth occurs in PYG-20\% bile broth or in deoxycholate broth. Indole, oxidase, DNase, and catalase are not produced, and nitrate is not reduced. Neither lipase nor lecithinase is detected on egg yolk agar (2). Resazurin is not reduced, and no gas is produced in PYG agar cultures.

The following amounts of fermentation products (in milliequivalents per $100 \mathrm{ml}$ of culture; mean \pm standard error of the mean) are produced in PYG broth cultures: acetate, $0.7 \pm$ 0.1 ; and isovalerate, $0.2 \pm 0.04$. Trace amounts of lactate, succinate, butyrate, and isobutyrate are also produced. No hydrogen is detected.

The type strain is ATCC 51276 (= VPI D94B-12). The reactions of the type strain are the same as those given above for the species.

The $\mathrm{G}+\mathrm{C}$ content of the type strain is $32 \mathrm{~mol} \%$.

Isolated from the gingival crevices of humans with gingivitis and periodontitis.

The cellular constituents, lack of pigment production, and $\mathrm{G}+\mathrm{C}$ content help differentiate this species from phenotypically similar anaerobic gram-negative bacilli.

Bacteroides pneumosintes. Bacteroides pneumosintes originally was described as Bacterium pneumosintes by Olitsky and Gates in 1921 (15), was transferred to the genus Dialister in 1923 (1), was placed in the genus Bacteroides in 1970 (4), and was excluded from the genus Bacteroides in 1989 (16). We propose that Bacteroides pneumosintes (incertae sedis) should be reclassified as Dialister pneumosintes (Olitsky and Gates 1921) comb. nov., nom. rev. The genus Dialister is differentiated from other genera in the family Bacteroidaceae by its small cell size and distinctive cellular fatty acid profile (Table 2). Of the genera of anaerobic gram-negative rods, only the genus Anaerorhabdus contains more than $20 \% \mathrm{C}_{16: 0} 3-\mathrm{OH}$ fatty acid. The genus Anaerorhabdus differs from the genus Dialister by fermenting fructose, glucose, and sometimes sucrose, by its larger cell size, and by producing major amounts of lactic acid (2).

Description of Dialister (Olitsky and Gates) nom. rev. Dialister (Di.a.lis'ter. etymology unknown). Dialister cells are minute, obligately anaerobic, nonmotile, nonsporing, nonfermentative, gram-negative bacilli. The major cellular constituents include $C_{18: 1} c i s-9$ fatty acid, $C_{16: 0}$ fatty acid, $C_{18: 0}$ fatty acid, and $\mathrm{C}_{16: 1}$ cis-9 fatty acid (Table 2). 1921).

The type species is Dialister pneumosintes (Olitsky and Gates

Description of Dialister pneumosintes comb. nov. Dialister pneumosintes (pneu.mo.sin'tes. Gr. N. pneuma, air; Gr. n. sintes, spoiler, thief; M.L. adj. pneumosintes, breath destroying). In addition to the characteristics given in Bergey's Manual of Systematic Bacteriology (3), trace amounts of acetate (mean, $0.07 \mathrm{meq} / 100 \mathrm{ml}$; range, 0 to $0.37 \mathrm{meq} / 100 \mathrm{ml}$ ), propionate (mean, $0.04 \mathrm{meq} / 100 \mathrm{ml}$; range, 0 to $0.06 \mathrm{meq} / 100 \mathrm{ml}$ ), lactate (mean, $0.06 \mathrm{meq} / 100 \mathrm{ml}$; range, 0 to $0.23 \mathrm{meq} / 100 \mathrm{ml}$ ), and succinate (mean, $0 \mathrm{meq} / 100 \mathrm{ml}$; range, 0 to $0.03 \mathrm{meq} / 100 \mathrm{ml}$ ) may be produced in PYG broth cultures. Additional characteristics are shown in Table 2.

The type strain is ATCC 33048. The reactions of the type strain are the same as those for the species. The $G+C$ content of the DNA has not been determined.
Isolated from gingival crevices $(6,11,12)$ and upper respiratory tracts of humans, from brain abscesses, and from infections of respiratory tracts, heads, and necks (3).

Inasmuch as the genera Oribaculum, Catonella, Hallella, Johnsonella, and Dialister are composed of anaerobic, gramnegative, nonsporing bacilli, they are members of the family Bacteroidaceae.

\section{ACKNOWLEDGMENTS}

We gratefully acknowledge the help of Pauletta C. Atkins, Martina T. Bullard, Polly H. Cooper, Jane L. Hungate, Kathy H. Pennington, and Sue C. Smith for microbiological studies, Ann P. Donnelly for electrophoretic and chromatographic studies, and Claudine Saville for technical assistance. We are grateful to John L. Johnson for performing the analyses of the $\mathrm{G}+\mathrm{C}$ contents of the DNAs of the new taxa. We are indebted to Thomas O. MacAdoo, Professor Emeritus, Virginia Polytechnic Institute and State University, for suggesting appropriate names for taxa and providing the etymologies. We appreciate critical reviews of the manuscript by J.-S. Chen and J. L. Johnson.

This work was supported by program project grant DE 08972 from the National Institute of Dental Research, National Institutes of Health, and by grant VA 135145 from the Cooperative State Research Service, U.S. Department of Agriculture.

\section{REFERENCES}

1. Bergey, D. H., F. C. Harrison, R. S. Breed, B. W. Hammer, and F. M. Huntoon. 1923. Bergey's manual of determinative bacteriology, p. 271-272. The Williams \& Wilkins Co., Baltimore.

2. Holdeman, L. V., E. P. Cato, and W. E. C. Moore (ed.). 1977. Anaerobe laboratory manual, 4th ed. Virginia Polytechnic Institute and State University Anaerobe Laboratory, Blacksburg.

3. Holdeman, L. V., R. W. Kelly, and W. E. C. Moore. 1984. Genus 1. Bacteroides Castellani and Chalmers 1919, 959 ${ }^{\mathrm{AL}}$, p. 604-631. In N. R. Krieg and J. G. Holt (ed.), Bergey's manual of systematic bacteriology, vol. 1. The Williams \& Wilkins Co., Baltimore.

4. Holdeman, L. V., and W. E. C. Moore. 1970. Outline of clinical methods in anaerobic microbiology, 2nd rev., p. 33. Virginia Polytechnic Institute and State University, Anaerobe Laboratory, Blacksburg.

5. Johnson, J. L., L. V. H. Moore, B. Kaneko, and W. E. C. Moore. 1990. Actinomyces georgiae sp. nov., Actinomyces gerencseriae sp. nov., designation of two genospecies of Actinomyces naeslundii, and inclusion of $A$. naeslundii serotypes II and III and Actinomyces viscosus serotype II in $A$. naeslundii genospecies 2 . Int. J. Syst. Bacteriol. 40:273-286.

6. Moore, L. V. H., W. E. C. Moore, E. P. Cato, R. M. Smibert, J. A. Burmeister, A. M. Best, and R. R. Ranney. 1987. Bacteriology of human gingivitis. J. Dent. Res. 66:989-995.

7. Moore, W. E. C., D. E. Hash, L. V. Holdeman, and E. P. Cato. 1980. Polyacrylamide slab gel electrophoresis of soluble proteins for studies of bacterial floras. Appl. Environ. Microbiol. 39:900907.

8. Moore, W. E. C., L. V. Holdeman, E. P. Cato, I. J. Good, E. P. Smith, R. R. Ranney, and K. G. Palcanis. 1984. Variation in periodontal floras. Infect. Immun. 46:720-726.

9. Moore, W. E. C., L. V. Holdeman, E. P. Cato, R. M. Smibert, J. A. Burmeister, K. G. Palcanis, and R. R. Ranney. 1985. Comparative bacteriology of juvenile periodontitis. Infect. Immun. 48:507-519.

10. Moore, W. E. C., L. V. Holdeman, E. P. Cato, R. M. Smibert, J. A. Burmeister, and R. R. Ranney. 1983. Bacteriology of moderate (chronic) periodontitis in mature adult humans. Infect. Immun. 42:510-515.

11. Moore, W. E. C., L. V. Holdeman, R. M. Smibert, E. P. Cato, J. A. Burmeister, K. G. Palcanis, and R. R. Ranney. 1984. Bacteriology of experimental gingivitis in children. Infect. Immun. 46:1-6.

12. Moore, W. E. C., L. V. Holdeman, R. M. Smibert, I. J. Good, J. A. Burmeister, K. G. Palcanis, and R. R. Ranney. 1982. Bacteriology of experimental gingivitis in young adult humans. Infect. Immun. 38:651-667. 
13. Moore, W. E. C., L. V. Holdeman, R. M. Smibert, D. E. Hash, J. A. Burmeister, and R. R. Ranney. 1982. Bacteriology of severe periodontitis in young adult humans. Infect. Immun. 38:11371148.

14. Moore, W. E. C., L. H. Moore, R. R. Ranney, R. M. Smibert, J. A. Burmeister, and H. A. Schenkein. 1991. The microflora of periodontal sites showing active destructive progression. J. Clin.
Periodontol. 18:729-739.

15. Olitsky, P. K., and F. L. Gates. 1921. Experimental studies of the naso-pharyngeal secretions from influenza patients. J. Exp. Med. 33:713-729.

16. Shah, H. N., and M. D. Collins. 1989. Proposal to restrict the genus Bacteroides (Castellani and Chalmers) to Bacteroides fragilis and closely related species. Int. J. Syst. Bacteriol. 39:85-87. 